\title{
Resistance in Annual Medicago spp. to Phoma medicaginis and Leptosphaerulina trifolii and Its Relationship to Induced Production of a Phytoestrogen
}

\author{
Martin J. Barbetti, School of Plant Biology, Faculty of Natural and Agricultural Sciences, The University of West- \\ ern Australia, Crawley, W.A. 6009 Australia; and Department of Agriculture and Food Western Australia, Baron-Hay \\ Court, South Perth, W.A. 6151, Australia
}

\begin{abstract}
Barbetti, M. J. 2007. Resistance in annual Medicago spp. to Phoma medicaginis and Leptosphaerulina trifolii and its relationship to induced production of a phytoestrogen. Plant Dis. 91:239-244.

Foliar and stem diseases of annual Medicago spp. caused by Phoma medicaginis and Leptosphaerulina trifolii can not only reduce yield, but also affect herbage quality by inducing the production of the phytoestrogen coumestrol. To determine differences in host reaction to these pathogens, 33 cultivars and lines in 1993 and 10 cultivars in 1995 were evaluated in inoculated field tests. In the 1993 test, a number of genotypes with high levels of resistance to leaf and stem disease caused by P. medicaginis and to leaf disease caused by L. trifolii were identified. Genotypes with very high levels of resistance to stem disease caused by $P$. medicaginis were $M$. sphaerocarpos GRC5659.4.1 and SAD10069, M. murex GRC87.1, GRC707, and GRC708, M. truncatula Z771, and M. solerolii DZA3180.1, all of which had stem disease scores of $\leq 1.0$ (scale 0 to 10) by the end of the growing season. The levels of coumestrol produced ranged from 114 to $1,230 \mathrm{ppm}$ dry weight in stems across the genotypes, and the score for stem disease caused by $P$. medicaginis in the corresponding cultivars ranged from $\leq 0.8$ to 8.9 , respectively. The 1995 test confirmed the relative responses of nine cultivars (Caliph, Circle Valley, Cyprus, Harbinger AR, Zodiac, Paraggio, Santiago, Serena, and Orion) of annual Medicago spp. to leaf and stem disease caused by P. medicaginis and to stem disease caused by L. trifolii. Those with the lowest levels of coumestrol in the stems were M. solerolii DZA3180.1, M. truncatula Paraggio, and M. sphaerocarpos SAD10069, all with levels $\leq 130 \mathrm{ppm}$. The highest level was found in M. polymorpha SA4178 (1,230 ppm). M. littoralis Harbinger AR, Z286, Z298, and Z912, M. murex 89F16.1.1, M. orbicularis SA8460, and M. polymorpha SA4188, all had coumestrol levels of $>600 \mathrm{ppm}$. For stem disease caused by $P$. medicaginis in particular, there was significant correlation of the level of disease with the level of coumestrol in stems at the end of the growing season. In contrast, for $L$. trifolii, there was significant negative correlation (leaf disease) or only a weak positive correlation (stem disease) with coumestrol in stems at the end of the growing season. Incorporation of these identified disease resistances into commercial cultivars offers a promising avenue not only as a long-term strategy for management of foliar diseases in annual Medicago spp., but also as a means of reducing phytoestrogen levels in commercial annual Medicago spp. pastures in order to minimize the adverse effects of phytoestrogens on fertility levels in sheep.
\end{abstract}

Stem and leaf spots caused by one or more Phoma and Leptosphaerulina species can cause significant losses to forage production in subterranean clover (Trifolium subterraneum) in southern Australia (4). Phoma black stem disease, caused by Phoma medicaginis and also known as spring black stem and leaf spot on alfalfa (26), is also an important fungal disease of Medicago species in Europe, North America, South Africa, and Australia $(1,8,9,22$, 24,25,31,33,34). In Western Australia, it is a major problem in the second year after seeding in most annual Medicago spp.

Corresponding author: M. J. Barbetti

E-mail: mbarbett@cyllene.uwa.edu.au

Accepted for publication 9 September 2006.

DOI: 10.1094/PDIS-91-3-0239

(C) 2007 The American Phytopathological Society stands, and poses a potential threat to susceptible cultivars $(2,11,24)$, especially in rainfall areas of $>350 \mathrm{~mm}$ per year with long pasture phases between cereal crops (10-12). Yield losses can be substantial. Reductions in herbage production of up to $16 \%$ and seed yield of up to $20 \%$ have been reported in grazed swards, while losses of herbage and seed of up to 32 and $53 \%$, respectively, have been reported in cause complete defoliation and premature death of very susceptible annual Medicago spp., particularly in lush stands during wet weather (1).

Pepper spot disease, caused by Leptosphaerulina trifolii, commonly occurs wherever annual Medicago spp. are grown, including Europe, South Africa, North America, and Australia $(4,8,9,22$, 25,27,29,32). In Australia, it can cause substantial yield losses in susceptible cultivars (12). ungrazed swards $(6,7)$. This disease can
Identification of host resistance to necrotrophic foliar pathogens has frequently been a key aim of annual Medicago spp. cultivar development programs, especially as there is large variability within annual Medicago spp. for resistance to diseases such as Phoma black stem disease $(2,3,5,7,31,32,36)$. Some resistance to stem and leaf disease of annual Medicago spp. has previously been identified for pepper spot disease, both in Australia (12) and in North America $(23,32)$.

Diseases such as Phoma black stem are also known to stimulate production of phytoestrogenic compounds such as coumestrol $(10,12,15,21)$ on annual Medicago spp. to levels between 300 and 550 ppm in stems and/or burrs in ungrazed swards, and levels in excess of $1,000 \mathrm{ppm}$ have been recorded for $M$. tornata $\mathrm{cv}$. Swani $(7,8,10,12)$. However, in all these studies, only the level of coumestrol was assessed, and other coumestans such as 4'-O-methyl coumestrol (14) were not included, as coumestrol is the most easily measured of these phytoestrogenic compounds. While phytoestrogens may provide some advantage to the host in terms of providing protection against attack by pests, significant amounts of phytoestrogenic compounds (34), perhaps even levels as low as 25 ppm dry weight in annual Medicago spp. pastures (16), can affect ovulation rates in sheep. A previous survey of annual Medicago spp. pastures in Western Australia indicated that very high levels of both foliar disease and coumestrol can sometimes occur together (16-19). Response to disease varies between genotypes for the quantity of phytoestrogens produced $(10,12)$. The severe losses from $P$. medicaginis and $L$. trifolii in susceptible annual Medicago spp. and the coumestrol stimulation associated with this infection (12) emphasize the need for future cultivars to carry resistance to both the pathogens as well as a low predisposition to coumestrol production.

This paper reports field screening of advanced breeding lines and/or cultivars of eight different annual Medicago spp. to identify resistance to $P$. medicaginis and $L$. trifolii and also to evaluate the relationship of resistance to disease within these genotypes with stimulation of coumestrol production in host tissues in response to these two pathogens. 


\section{MATERIALS AND METHODS}

Field tests. Field tests were conducted in 1993 and 1995 to determine the reaction of genotypes and cultivars of annual Medicago spp. to $P$. medicaginis and L. trifolii and the accumulation of the phytoestrogen coumestrol. The test genotypes and cultivars were sown by hand at $40 \mathrm{~kg} / \mathrm{ha}$ in 0.8 $\times 0.8 \mathrm{~m}$ plots at the Department of Agriculture and Food Western Australia's Medina Experimental Station (latitude $32^{\circ} 13^{\prime}$ S; longitude $115^{\circ} 48^{\prime}$ E), Medina, Western Australia, on 6 May 1993 or 9 May 1995 by spreading seed over the plot surface and lightly raking to cover the seed with soil. The soil type was a yellow sandy soil with a Northcote Convention code of Uc4.2 (30). Seed was inoculated with an appropriate rhizobial strain, and seed was lime pelleted prior to sowing in order to protect the rhizobia coated onto the seed. Approximately $200 \mathrm{~kg} / \mathrm{ha}$ of metham sodium was applied to the soil using commercial soil-injection equipment 5 weeks prior to sowing, and the fumigated area was then watered by overhead sprinklers immediately following application of the metham sodium to minimize escape of the fumigant into the atmosphere. Fertilizer applications were according to standard practice and included superphosphate at $200 \mathrm{~kg} / \mathrm{ha}$ and muriate of potash at $50 \mathrm{~kg} / \mathrm{ha}$ topdressed prior to seeding. Subsequently, a 4:1 ratio mix of superphosphate and muriate of potash was applied at the end of June and again in late August. Dimethoate at 60 $\mathrm{ml} / \mathrm{ha}$ was applied at the end of June and again at the end of August to control any redlegged earth mites (Halotydeus destructor) and/or aphid species present. All plots were watered as required using overhead sprinklers, and were surrounded by a 1-m bare ground buffer.

In 1993, 33 annual Medicago spp. genotypes and cultivars, $M$. murex, Zodiac, 89FO5.5.1, 89FB6.1.1.3, 89F16.1.1, 89F17.4.3, GRC707, GRC708, GRC87.1; M. sphaerocarpos, 89 N19.5.1.1, GRC5659.4.1, SAD10069, Orion; $M$. polymorpha, Serena, Santiago, Circle Valley, SA4178, SA4188, SA5709, SA21255; $M$. orbicularis, SA8460; M. tornata, MCD39C; M. littoralis, Z905, Z245, Z286, Z298, Z912, Harbinger AR; M. truncatula, Paraggio, Mogul, Z771, Caliph, Cyprus; and $M$. solerolii, DZA3180.1, were examined. Seed of cultivars was obtained from commercial certified seed, and seed of advanced breeding lines was obtained from the Australian Medicago Genetic Resource Centre, South Australia. Genotypes were replicated four times in a randomized block design.

In 1995, 10 cultivars of annual Medicago spp., Caliph, Circle Valley, Cyprus, Harbinger AR, Herald, Zodiac, Paraggio, Santiago, Serena, and Orion, were examined to confirm their relative responses to $P$. medicaginis and to L. trifolii. Cultivars were replicated four times in a randomized block design.
Pathogen inoculation and disease assessment. Senesced annual $M$. polymorpha plants infected with both $P$. medicaginis and $L$. trifolii, collected at the end of the 1992 growing season from infested commercial stands of annual Medicago spp., was used in both the 1993 and 1995 tests. Following collection, inoculum was stored at room temperature until needed, and was distributed by hand at $830 \mathrm{~kg} / \mathrm{ha}$ across each plot on 13 May 1993 (1993 test) or 15 May 1995 (1995 test).

Once disease development had become evident, plots were assessed at approximately 4 weekly intervals throughout the season for any fungal diseases present. In 1993, assessments for leaf disease caused by $P$. medicaginis and $L$. trifolii were made on 15 June, 12 July, 10 August, and 8 and 30 September. In 1995, assessments for leaf disease caused by $P$. medicaginis and L. trifolii were only made on 8 August. In both tests and for all disease assessments, independent visually assessed scores for each plot were made by two different assessors, and these two scores were averaged to present a single assessment per genotype.

Leaf disease was assessed by decile rankings of affected leaf number on a 0 to 10 scale, where $0=$ no disease, $1=>1$ to $10,2=>10$ to $20,3=>20$ to $30,4=>30$ to $40,5=>40$ to $50,6=>50$ to $60,7=$ $>60$ to $70,8=>70$ to $80,9=>80$ to 90,10 $=>90 \%$ of leaves affected. In 1993, only data for the 10 August assessment are presented, as this is the date when the disease scores for leaf disease caused by either $P$. medicaginis or L. trifolii peaked during the assessment period. The leaf symptoms of the diseases were clearly visually distinguishable and confirmed by occasional isolation onto moist blotter and/or nutrient agar plates.

For stem disease caused by $P$. medicaginis and L. trifolii in 1993, plots were assessed on 10 August, 8 and 30 September, and 27 October. Only data for the 27 October assessment are presented, as this is the date when the stem disease scores peaked for both diseases. The reason for assessments for stem disease caused by $P$. medicaginis commencing on 10 August while those for stem disease caused by $L$. trifolii commenced on 8 September was due to the latter disease being slower to become evident in plots. For the 1995 test for stem disease caused by $P$. medicaginis, plots were assessed on 7 and 27 September (only data for 27 September is presented), while for stem disease caused by $L$. trifolii, a single assessment was made on 27 October.

Stem disease was assessed by decile rankings of affected stems on a 0 to 10 scale where $0=$ no disease, $1=>0$ to $10 \%$ of stems with small lesions; $2=>10$ to $20 \%$ of stems with small lesions; $3=>20$ to $30 \%$ of stems with lesions; $4=>30$ to $40 \%$ of stems with lesions; $5=>40$ to $50 \%$ of stems with lesions; $6=>50$ to $60 \%$ of stems with mostly severe lesions; $7=>60$ to $70 \%$ of stems with severe lesions; $8=$ $>70$ to $80 \%$ of stems with severe lesions and occasional stems collapsing from disease; $9=>80$ to $90 \%$ of stems with severe lesions and some stems collapsing; and 10 $=>90$ to $100 \%$ of stems collapsed from disease. The stem symptoms of the diseases were easily distinguished visually (dark brown to black lesions for P. medicaginis and small black "pepper spot" spots and/or lesions with light brown to tan centers for $L$. trifolii) and were also confirmed by occasional isolation onto moist blotter and/or nutrient agar plates. Each plot was scored by two assessors and the mean score used for analysis.

In both 1993 and 1995, stem samples were taken in early November from all plots for analysis of the content of the phytoestrogen coumestrol. Samples were oven dried at $70^{\circ} \mathrm{C}$, finely ground using a coffee grinder, and assayed by thin-layer chromatography using a method based on Beck (13) and Francis and Millington (20). The method is semi-quantitative, and the values presented were calculated in comparison to standards of known coumestrol concentration.

Data analysis. Data were analyzed using Genstat (7th ed., Lawes Agricultural Trust, Rothamsted Experimental Station). Significant differences among means were assessed by least significant difference (LSD). Regression analysis was used to determine the relationship of $P$. medicaginis and L. trifolii disease scores to the level of coumestrol in stems.

\section{RESULTS}

1993 Field test. A number of genotypes with high levels of resistance to leaf disease caused by $P$. medicaginis were identified, including $M$. littoralis Z905 and $M$. truncatula Paraggio and Z771, both with scores of $<1.0$ by end of season (Table 1 ). This is in contrast to $M$. polymorpha Serena, Santiago, and Circle Valley, $M$. murex 89FB6.1.13, and M. sphaerocarpos Orion, all with leaf disease scores $\geq 2.9$ by end of season.

A number of genotypes with very high levels of resistance to stem disease caused by $P$. medicaginis were identified, including M. sphaerocarpos GRC5659.4.1 and SAD10069, M. murex GRC87.1, GRC707, and GRC708, M. truncatula Z771, and $M$. solerolii DZA3180.1, which all had stem disease scores of $\leq 1.0$ by the end of the growing season (Table 1). This is in comparison with other genotypes that showed high stem disease scores, such as cultivars M. polymorpha Serena (score 4.9) and Santiago (score 4.3), and some highly susceptible breeding lines such as M. polymorpha SA4178, SA4188, and SA21255 (scores $\geq 8.9$ ) and $M$. orbicularis SA8460 (score 7.0).

The majority of genotype lines tested were highly susceptible to leaf disease 
caused by L. trifolii (scores 3.2 to 5.5) (Table 1). The lines with the least disease were M. littoralis Z245, Z286, Z298, and Z905, and $M$. polymorpha SA4178, SA4188, and SA5709, all with leaf disease scores of $\leq 3.5$.

A number of genotypes showed no stem disease whatsoever caused by $L$. trifolii, including M. murex Zodiac and GRC708, M. orbicularis SA8460, M. polymorpha Circle Valley, Serena, Santiago, SA4178, and SA5709, $M$. solerolii DZA3180.1, $M$. sphaerocarpos Orion, GRC5659.4.1, SAD10069, and 89N19.5.1.1 (Table 1). The most susceptible genotypes to stem disease caused by $L$. trifolii were $M$. truncatula Caliph and Cyprus and M. littoralis Z298 and Z905, all with stem disease scores of $\geq 1.8$ by the end of the growing season.

While there was no overall correlation between the leaf disease scores for $P$. medicaginis at 10 August with the stem disease scores for $P$. medicaginis at 27 October $(r=0.12, n=32, n s)$, there was significant negative correlation between the leaf disease scores for L. trifolii at 10 August and stem disease scores for $L$. trifolii at 27 October $(r=-0.42, n=32, P<$ 0.05).

Levels of coumestrol produced in inoculated field swards ranged from 114 to 1,230 ppm across the genotypes (Table 1). Those with the lowest levels of coumestrol were $M$. solerolii DZA3180.1, M. truncatula Paraggio, and $M$. sphaerocarpos SAD10069, all with coumestrol levels $\leq 130 \mathrm{ppm}$. An extremely high level was found in $M$. polymorpha SA4178 (1,230 ppm). M. littoralis Harbinger AR, Z286, Z298, and Z912, M murex 89F16.1.1, $M$. orbicularis SA8460, and M. polymorpha SA4188 all showed high levels of coumestrol at $>600 \mathrm{ppm}$.

For leaf disease caused by $P$. medicaginis, there was significant positive correlation of the incidence of leaf disease at 12 July and at 30 September, but not at 15 June, 10 August, or at 8 September, with the level of coumestrol in stems at the end of the growing season (Table 2).

For leaf disease caused by L. trifolii, there was significant negative correlation of leaf disease score at 15 June, at 12 July, at 10 August, and at 8 September, but not at 30 September, with the level of coumestrol in stems at the end of the growing season (Table 2).

For stem disease caused by $P$. medicaginis, there was significant correlation of the score for stem disease at 10 August, at 8 September, at 30 September, and at 27 October with the level of coumestrol in stems at the end of the growing season (Table 2).

For stem disease caused by L. trifolii, there was a weak positive correlation of stem disease score at 8 September but no significant correlation of stem disease at 30 September, nor at 27 October, with the level of coumestrol in the stems at the end of the growing season (Table 2).

1995 Field test. For leaf disease caused by $P$. medicaginis, $M$. murex Zodiac had the least amount of disease, with a disease score of 0.8. M. truncatula Cyprus and $M$. littoralis Harbinger appeared to be the next most resistant with disease scores $\leq 1.8$ (Table 3). The most susceptible cultivars were M. polymorpha Santiago, Serena, and Circle Valley, all with disease scores of $\geq 5$.0.

For leaf disease caused by L. trifolii, $M$. polymorpha Circle Valley had the lowest disease score of 0.9 followed by M. polymorpha Serena and M. littoralis Herald with scores $\leq 2.0$ (Table 3 ). The most susceptible cultivars were $M$. truncatula Caliph, M. murex Zodiac, and M. littoralis Harbinger AR, all with scores $\geq 5.0$.

For stem disease caused by $P$. medicaginis, $M$. truncatula Paraggio had the lowest disease score of 0.7 , followed by $M$. littoralis Harbinger, M. sphaerocarpos Orion, and $M$. murex Zodiac, all with disease scores $\leq 2.0$ (Table 3 ). The most susceptible cultivars were $M$. polymorpha Serena and $M$. truncatula Cyprus, with disease scores $\geq 5.9$.

For stem disease caused by L. trifolii, overall disease scores were very low and there was no disease at all on M. polymor-

Table 1. 1993 Field test: Foliar disease scores for Phoma medicaginis or Leptosphaerulina trifolii on 33 annual Medicago genotypes grown in artificially infested and ungrazed plots at Medina, Australia, $1993^{\mathrm{a}}$

\begin{tabular}{|c|c|c|c|c|c|}
\hline \multirow{2}{*}{$\begin{array}{l}\text { Medicago } \\
\text { species and } \\
\text { genotype }\end{array}$} & \multicolumn{2}{|c|}{$\begin{array}{l}\text { Leaf disease score } \\
(0-10 \text { scale })^{\mathrm{b}}\end{array}$} & \multicolumn{2}{|c|}{$\begin{array}{c}\text { Stem disease score } \\
\left(0-10 \text { scale }^{\mathbf{b}}\right.\end{array}$} & \multirow{2}{*}{$\begin{array}{l}\text { Coumestrol } \\
\text { (ppm dry wt) }\end{array}$} \\
\hline & P. medicaginis & L. trifolii & P. medicaginis & L. trifolii & \\
\hline \multicolumn{6}{|l|}{ M. littoralis } \\
\hline Harbinger AR & 1.1 & 3.6 & 3.0 & 1.4 & 605 \\
\hline Z245 & 1.3 & 3.4 & 3.4 & 1.3 & 490 \\
\hline Z286 & 1.0 & 3.4 & 4.3 & 1.5 & 678 \\
\hline Z298 & 1.6 & 3.0 & 4.3 & 1.8 & 695 \\
\hline Z905 & 0.8 & 3.4 & 3.4 & 1.9 & 583 \\
\hline Z912 & 1.0 & 3.9 & 4.5 & 1.6 & 760 \\
\hline \multicolumn{6}{|l|}{ M. murex } \\
\hline Zodiac & 2.1 & 3.8 & 0.3 & 0 & 329 \\
\hline 89FB6.1.13 & 3.0 & 3.6 & 4.6 & 1.3 & 513 \\
\hline 89FO5.5.1 & 2.7 & 4.7 & 2.9 & 0.6 & 518 \\
\hline $89 F 16.1 .1$ & 2.2 & 5.0 & 1.4 & 0.1 & 391 \\
\hline $89 \mathrm{~F} 17.4 .3$ & 1.8 & 4.0 & 5.6 & 0 & 603 \\
\hline GRC87.1 & 2.1 & 4.9 & 0.9 & 0.2 & 279 \\
\hline GRC707 & 1.5 & 4.9 & 0.5 & 0.1 & 293 \\
\hline GRC708 & 1.5 & 5.3 & 0.2 & 0 & 204 \\
\hline \multicolumn{6}{|l|}{ M. orbicularis } \\
\hline SA8460 & 1.7 & 4.4 & 7.0 & 0 & 718 \\
\hline \multicolumn{6}{|l|}{ M. polymorpha } \\
\hline Circle Valley & 2.9 & 3.6 & 3.0 & 0 & 490 \\
\hline Serena & 3.0 & 3.6 & 4.9 & 0 & 476 \\
\hline Santiago & 3.1 & 4.2 & 4.3 & 0 & 540 \\
\hline SA4178 & 1.6 & 3.2 & 8.9 & 0 & 1,230 \\
\hline SA4188 & 1.7 & 3.5 & 9.3 & 0.3 & 606 \\
\hline SA5709 & 2.4 & 3.2 & 2.1 & 0 & 308 \\
\hline SA21255 & 3.5 & 4.2 & 8.9 & 0.01 & 748 \\
\hline \multicolumn{6}{|l|}{ M. solerolii } \\
\hline DZA3180.1 & 1.4 & 5.4 & 0.3 & 0 & 114 \\
\hline \multicolumn{6}{|l|}{ M. sphaerocarpos } \\
\hline Orion & 3.5 & 4.1 & 1.4 & 0 & 315 \\
\hline GRC5659.4.1 & 2.0 & 5.0 & 0.2 & 0 & 190 \\
\hline SAD10069 & 1.7 & 4.0 & 0.3 & 0 & 130 \\
\hline 89N19.5.1.1 & 2.6 & 3.9 & 2.4 & 0 & 590 \\
\hline \multicolumn{6}{|l|}{ M. tornata } \\
\hline MCD39C & 1.6 & 3.8 & 1.9 & 0.8 & 414 \\
\hline \multicolumn{6}{|l|}{ M. truncatula } \\
\hline Caliph & 1.2 & 3.9 & 5.9 & 2.3 & 416 \\
\hline Cyprus & 1.0 & 4.1 & 5.1 & 1.8 & 425 \\
\hline Mogul & 1.2 & 3.9 & 1.6 & 1.1 & 158 \\
\hline Paraggio & 0.9 & 3.6 & 0.8 & 1.3 & 114 \\
\hline $\mathrm{Z771}$ & 0.9 & 4.0 & 0.5 & 0.5 & 164 \\
\hline Mean & 1.9 & 4.0 & 2.0 & 0.6 & 457 \\
\hline$F$ prob. $P<$ & 0.001 & 0.001 & 0.001 & 0.001 & 0.001 \\
\hline LSD $P<0.05$ & 0.98 & 0.89 & 1.37 & 0.45 & 217 \\
\hline
\end{tabular}

a Number of replications $=4$, arranged in a randomized block design. Plots were artificially infected by adding M. polymorpha trash infested with both Phoma medicaginis and Leptosphaerulina trifolii.

${ }^{\mathrm{b}}$ Disease assessment is on a 0 to 10 decile scale where $0=$ no disease and $10=>90 \%$ of leaves affected by leaf disease or complete collapse of the sward for stem disease. Disease assessments were made for leaf disease on 10 August and stem disease on 27 October. 
pha Circle Valley, Santiago, and Serena, Paraggio.

Lowest levels of coumestrol were found in M. truncatula Paraggio (77 ppm) and in M. truncatula Caliph and Cyprus, $M$. sphaerocarpos Orion, and M. murex Zodiac, which all had coumestrol levels $\leq 272$ ppm.

There was no significant correlation between disease and coumestrol level for the 1995 test.

Comparison of 1993 and 1995 tests. A comparison made between foliar disease M. sphaerocarpos Orion, or M. truncatula

scores in the 1993 test and those in the 1995 test for the 10 cultivars in common showed that there was a significant degree of correlation between the scores of leaf disease caused by $P$. medicaginis ( $r=0.71$, $n=9, P<0.05)$, the scores for stem disease caused by $P$. medicaginis ( $r=0.80, n$ $=9, P<0.01)$, and the scores for stem disease caused by $L$. trifolii $(r=0.81, n=$ $9, P<0.01)$, but not for the scores for leaf disease caused by L. trifolii $(r=0.06, n=$ 9, $n s)$. A comparison made between coumestrol levels in 1993 and those in 1995 for the same 10 cultivars showed that

Table 2. Level of correlation between foliar disease from Phoma medicaginis or Leptosphaerulina trifolii with the level of coumestrol (ppm dry wt) in the stems of 33 annual Medicago genotypes grown in artificially infested and ungrazed plots at Medina, Australia, 1993

\begin{tabular}{lccc}
\hline & \multicolumn{2}{c}{ Correlation $(\boldsymbol{r}=)$ with stem } & \\
\cline { 2 - 3 } Foliar disease & Assessment date & Coumestrol level $(\mathbf{p p m})$ & Significance $(\boldsymbol{P}<)$ \\
\hline Phoma & 15 June & 0.11 & $n s$ \\
leaf disease & 12 July & 0.21 & 0.05 \\
& 10 August & 0.16 & $n s$ \\
& 8 September & 0.08 & $n s$ \\
Leptosphaerulina & 30 September & 0.31 & 0.001 \\
leaf disease & 15 June & -0.20 & 0.05 \\
& 12 July & -0.26 & 0.01 \\
& 10 August & -0.31 & 0.001 \\
Phoma & 8 September & -0.27 & 0.001 \\
stem disease & 30 September & -0.15 & $n s$ \\
& 10 August & 0.42 & 0.001 \\
Leptosphaerulina & 8 September & 0.57 & 0.001 \\
stem disease & 30 September & 0.70 & 0.001 \\
& 27 October & 0.74 & 0.001 \\
8 September & 0.18 & 0.5 \\
\hline
\end{tabular}

a For all comparisons, $n=131$.

Table 3. 1995 Field test: Foliar disease scores for Phoma medicaginis or Leptosphaerulina trifolii and coumestrol levels in stems (ppm dry wt) for 10 annual Medicago genotypes grown in artificially infested and ungrazed plots at Medina, Australia, 1995

\begin{tabular}{|c|c|c|c|c|c|}
\hline \multirow{2}{*}{$\begin{array}{l}\text { Medicago species } \\
\text { and cultivar }\end{array}$} & \multicolumn{2}{|c|}{$\begin{array}{l}\text { Leaf disease score } \\
\quad(0-10 \text { scale })^{\mathrm{b}}\end{array}$} & \multicolumn{2}{|c|}{$\begin{array}{l}\text { Stem disease score } \\
(0-10 \text { scale })^{\mathbf{b}}\end{array}$} & \multirow{2}{*}{$\begin{array}{c}\text { Coumestrol } \\
\text { (ppm dry wt) }\end{array}$} \\
\hline & P. medicaginis & L. trifolii & P. medicaginis & L. trifolii & \\
\hline \multicolumn{6}{|l|}{ M. littoralis } \\
\hline Harbinger AR & 1.8 & 5.4 & 1.6 & 0.4 & 838 \\
\hline Herald & 2.5 & 2.0 & 3.9 & 0.8 & 1,209 \\
\hline \multicolumn{6}{|l|}{ M. murex } \\
\hline Zodiac & 0.8 & 5.5 & 2.0 & 0 & 272 \\
\hline \multicolumn{6}{|l|}{ M. polymorpha } \\
\hline Circle Valley & 5.0 & 0.9 & 4.3 & 0 & 464 \\
\hline Santiago & 5.5 & 3.4 & 4.0 & 0 & 362 \\
\hline Serena & 5.0 & 1.5 & 6.3 & 0 & 392 \\
\hline \multicolumn{6}{|l|}{ M. sphaerocarpos } \\
\hline Orion & 4.0 & 5.5 & 1.9 & 0 & 236 \\
\hline \multicolumn{6}{|l|}{ M. truncatula } \\
\hline Caliph & 2.8 & 5.0 & 4.8 & 0.6 & 242 \\
\hline Cyprus & 1.5 & 4.9 & 5.9 & 0.6 & 235 \\
\hline Paraggio & 3.2 & 3.8 & 0.7 & 0.1 & 77 \\
\hline Mean & 3.2 & 3.8 & 3.5 & 0.3 & 433 \\
\hline$F$ prob. $P<$ & 0.001 & 0.001 & 0.001 & 0.001 & 0.001 \\
\hline LSD $P<0.05$ & 1.52 & 1.40 & 1.50 & 0.26 & 250 \\
\hline
\end{tabular}

${ }^{a}$ Number of replications $=4$, arranged in a randomized block design. Plots were artificially infected by adding M. polymorpha trash infested with both Phoma medicaginis and Leptosphaerulina trifolii.

${ }^{\mathrm{b}}$ Disease assessment is on a $0-10$ decile scale where $0=$ no disease and $10=>90 \%$ of leaves affected by leaf disease or complete collapse of the Sward for stem disease. Disease assessments were made for leaf disease on 8 August for both pathogens and on 1 October and 27 September for Phoma and Leptosphaerulina stem disease, respectively. there was no significant correlation $(r=$ $0.01, n=9, n s)$.

\section{DISCUSSION}

This study highlights the availability of resistance to $P$. medicaginis across one or more genotypes of $M$. littoralis, $M$. murex, M. orbicularis, $M$. polymorpha, M. solerolii, M. sphaerocarpos, M. tornata, and $M$. truncatula. In particular, a number of genotypes with very high levels of resistance to stem disease caused by $P$. medicaginis were identified, including M. sphaerocarpos GRC5659.4.1 and SAD10069, M. murex GRC87.1, GRC707, and GRC708, M. truncatula Z771, and M. solerolii DZA3180.1, which all had stem disease scores of $\leq 1.0$ by the end of the growing season. In addition, a number of genotypes with high levels of resistance to leaf disease caused by $P$. medicaginis were identified, including M. littoralis Z905 and M. truncatula Paraggio and Z771. Importantly, a number of genotypes were identified that had no stem disease caused by $L$. trifolii, including $M$. murex Zodiac and GRC708, M. orbicularis SA8460, M. polymorpha Circle Valley, Serena, Santiago, SA4178, and SA5709, M. solerolii DZA3180.1, M. sphaerocarpos Orion, GRC5659.4.1, SAD10069, and 89N19.5.1.1. These new sources of resistance are especially suited to Mediterranean environments, where annual Medicago spp. are reliant upon having effective resistance against serious necrotrophic pathogens such as $P$. medicaginis and $L$. trifolii if they are to be productive (36). These sources of resistance could be useful both as parental materials for breeding better cultivars and, in some instances, perhaps directly released as new resistant cultivars (9). For providing practical benefits to farmers, the most important of these resistances is that expressed on stems against $P$. medicaginis, which is both the most damaging of the two diseases examined in the current study and also more damaging on stems rather than on leaves in terms of adverse impact upon herbage and seed yields $(8,10)$. Annual Medicago spp. cultivar development programs targeting disease resistance, such as those developed for Phoma black stem disease in Australia $(3,5,7)$, could be expanded. Incorporation of resistance into commercial cultivars offers the most promising long-term strategy for management of foliar diseases in annual medics $(11,36)$.

Levels of coumestrol produced in the artificially inoculated field swards varied widely, ranging from 114 to $1,230 \mathrm{ppm}$ across the genotypes tested. Some of the genotypes tested in the current study, such as $M$. solerolii DZA3180.1, M. truncatula Paraggio, and $M$. sphaerocarpos SAD10069, all with coumestrol levels $\leq 130 \mathrm{ppm}$ and stem disease resulting from $P$. medicaginis of $\leq 0.8$, offer significant potential for reducing the levels of phy- 
toestrogens in annual medic pastures, either by their direct deployment as cultivars or as parental material in annual Medicago spp. breeding programs. There were a number of genotypes that had coumestrol levels above $600 \mathrm{ppm}$ and one with a level of $1,230 \mathrm{ppm}$. Actual levels of total coumestrol could be higher since not all types of coumestrol are measured with the assay method used in this and other studies $(7,8,10,12,15,21)$. Phytoestrogenic compounds adversely affect ovulation rates in sheep $(16,35)$, even coumestrol levels as low as $25 \mathrm{ppm}$, and the rates reported in our current and the earlier studies often substantially exceeded $25 \mathrm{ppm}$. Hence, while it is probable that the production of phytoestrogens may provide some advantage to the host by providing protection against attack by pests, the adverse effects of phytoestrogen on animal productivity more than offset any potential benefits from their presence.

For stem disease caused by $P$. medicaginis, there was significant correlation of the level of disease with the level of coumestrol in stems at the end of the growing season. Production of phytoestrogenic compounds in response to disease is known to vary between accessions of annual Medicago spp. $(10,12)$, and the current study confirms this finding. Although a number of different types of stresses such as soil type (21) and nutrition (28) can also cause increases in coumestrol levels in annual Medicago spp., it is clear from the current study that there is a close relationship between the level of damage caused by $P$. medicaginis on stems and the phytoestrogen levels in stems. This suggests that annual Medicago breeders should focus in particular on selecting for high resistance to stem disease caused by $P$. medicaginis. Despite there being no significant overall correlation between coumestrol levels in the 1993 test and those in the 1995, some cultivars showed similar reactions for at least some of the disease components assessed (e.g., $M$. truncatula Cyprus and Paraggio) and/or also for coumestrol production (e.g., $M$. polymorpha Circle Valley and $M$. truncatula Paraggio) across both years. However, for some of the other cultivars at least, it appears that site and/or seasonal differences or other factors can also influence the relationship between the level of coumestrol with foliar disease caused by $P$. medicaginis and/or L. trifolii. The lack of overall relationship between the 1993 and 1995 coumestrol levels may also have been at least partially a consequence of the lack of relationship between disease and coumestrol level in the 1995 test. The current study, along with the earlier studies, suggests that sowing of more diseaseresistant cultivars could reduce current levels of coumestrol in annual Medicago spp. swards in response to the presence of pathogens (9) and may be a useful way of dealing with sheep fertility issues associated with high levels of phytoestrogens.

It is clear, for reasons of both reducing yield losses and phytoestrogen levels in annual Medicago spp. pastures, that all new annual medics released for regions where Phoma black stem disease in particular is common should possess adequate host resistance. In Australia, despite the identification of a significant number of sources of host resistance, breeders have not delivered this benefit to farmers by way of more disease resistant cultivars. Even where host resistance has been identified, it is clear that the mechanisms and/or genetic basis of such resistances have yet to be defined.

\section{ACKNOWLEDGMENTS}

I thank Australian Wool International and the Grains Research and Development Corporation for their financial support, P. Skinner and K. Foster for technical assistance, D. Ambrose, R. Lugg, and B. Roberts of the Isoflavone Testing Laboratory at the University of Western Australia Field station for conducting coumestrol analyses, and $\mathrm{C}$. $\mathrm{Li}$ and $\mathrm{M}$. You for assistance with statistical analyses.

\section{LITERATURE CITED}

1. Barbetti, M. J. 1983. Fungal foliage diseases of pasture legumes. J. Agric. West. Aust. 4th ser. 1:10-12.

2. Barbetti, M. J. 1987. Effects of temperature and humidity on disease caused by Phoma medicaginis, resistance in some Medicago cultivars and the incidence of seed-borne inoculum. Aust. J. Exp. Agric. 27:851-856.

3. Barbetti, M. J. 1989. Strategies for control of Phoma black stem in annual Medicago species. Aust. J. Exp. Agric. 29:635-640

4. Barbetti, M. J. 1989. Fungal diseases of pasture legumes in Western Australia. Department of Agriculture, Western Australia, Bull. No. 4133 .

5. Barbetti, M. J. 1990. Resistance in annual Medicago species to Phoma medicaginis under controlled environment and field conditions. Aust. J. Exp. Agric. 30:209-214

6. Barbetti, M. J. 1992. Efficacy of fungicides for control of Phoma black stem and Pseudopeziza leaf spot in annual Medicago polymorpha var. brevispina. Plant Prot. Quart. 7:21-22.

7. Barbetti, M. J. 1993. Phoma black stem disease - A threat to susceptible annual medic pastures. Pages 929-930 in: Proc. XVII International Grasslands Congr. New Zealand Grassland Association, Tropical Grasslands Society of Australia, New Zealand Society of Animal Production, Australian Society of Animal Production - Queensland Branch, New Zealand Institute of Agricultural Science.

8. Barbetti, M. J. 1995. Relative resistance, associated yield losses and phyto-oestrogen production from fungal foliar diseases in new and old annual Medicago cultivars. Aust. J. Agric. Res. 46:441-450.

9. Barbetti, M. J. 1995. Resistance in annual Medicago species to Phoma medicaginis and Leptospherulina trifolii under field conditions. Aust. J. Exp. Agric. 35:209-214.

10. Barbetti, M. J., and Fang, C. S. 1991. Relationship between Phoma black stem severity and herbage and seed yield and coumestrol content in three Medicago polymorpha var. brevispina cultivars. Aust. J. Agric. Res. 42:409-415.

11. Barbetti, M. J., and Nicholas, D. A. 1997. Effect of Phoma black stem and pepper spot diseases on yield, regeneration, sward compo- sition and phyto-oestrogen levels in grazed annual medic pastures. Page 65 in: Proc. Aust Plant Pathol. Soc. Bienn. Conf., Perth.

12. Barbetti, M. J., and Nichols, P. G. H. 1991 Effect of Phoma medicaginis and Leptosphaerulina trifolii on herbage and seed yield and coumestrol content of annual Medicago species. Phytophylactica 23:223-227.

13. Beck, A. B. 1964. The oestrogenic isoflavones of subterranean clover. Aust. J. Agric. Res. 15:223-230.

14. Bickoff, E. M., Livingston, A. L., Witt, S. C. Lundin, R. E., and Spencer, R. R. 1965. Isolation of 4'-O-methyl coumestrol from alfalfa. J. Agric. Food Chem. 13:597-602.

15. Collins, W. J., and Cox, R. I. 1984. Oestrogenic activity in forage legumes. Pages 268276 in: Proc. Trilateral Workshop on Forage Legumes for Energy-efficient Animal Production, Palmerston North, New Zealand. U.S Dep. Agric. Agric. Res. Serv.

16. Croker, K., Barbetti, M. J., and Nichols, P. G. H. 1994. Incidence of coumestrol in medic pastures in Western Australia. Proc. Aust. Soc. Anim. Prod. 20:416.

17. Croker, K., Nichols, P. G. H., Barbetti, M. J., and Adams, N. 1994. Sheep infertility from pasture legumes. Dep. Agric. West. Aust., Farmnote No. 6/94.

18. Croker, K., Nichols, P. G. H., Barbetti, M. J., and Adams, N. 1999. Sheep infertility from pasture legumes. Dep. Agric. West. Aust., Farmnote No. 79/99.

19. Croker, K., Nichols, P., Barbetti, M. J., and Adams, N. 2005. Sheep infertility from pasture legumes. Dep. Agric. West. Aust., Farmnote 41/2005.

20. Francis, C. M., and Millington, A. J. 1965. Varietal variation in the isoflavone content of subterranean clover: Its estimation by a microtechinque. Aust. J. Agric. Res. 16:557564.

21. Francis, C. M., and Millington, A. J. 1971. The presence of methylated coumestans in annual Medicago species: Response to a fungal pathogen. Aust. J. Agric. Res. 22:75-80.

22. Graham, J. H., Frosheiser, F. I., Stuteville, D. L., and Erwin, D. C. 1979. A Compendium of Alfalfa Diseases. American Phytopathological Society, St. Paul, MN.

23. Hill, R. R., and Leath, K. T. 1979. Comparison of four methods of selection for resistance to Leptosphaerulina briosiana in alfalfa. Can. J. Gen. Cytol. 21:179-186.

24. Johnstone, G. R., and Barbetti, M. J. 1987. Impact of fungal and virus diseases in pastures. Pages 235-248 in: Temperate Pastures: Their Production, Use and Management. J. L. Wheeler, C. J. Pearson, and G. E. Robards, eds. Australian Wool Corporation/Commonwealth Scientific and Industrial Research Organization, Melbourne, Australia.

25. Lamprecht, S. C., and Knox-Davies, P. S. 1984. Preliminary survey of foliage disease of annual Medicago spp. in South Africa. Phytophylactica 16:177-183.

26. Leath, K. T. 1990. Spring black stem and leaf spot. Pages 16-17 in: Compendium of Alfalfa Diseases, 2nd ed. D. L. Stuteville and D. C. Erwin, eds. American Phytopathological Society, St Paul, MN.

27. Leath, K. T., Erwin, D. C., and Griffin, G. D. 1988. Diseases and nematodes. Pages 621-670 in: Alfalfa and Alfalfa Improvement. Agronomy Monograph No. 29. American Society of Agronomy, Crop Science Society of America, Soil Science Society of America, Madison, WI.

28. Marshall, T., and Parkin, R. J. 1971. Phosphate applications affect the coumestrol level of medics. J. Agric. West. Aust. 11:180.

29. Martinez, E. S., and Hanson, E. W. 1963. Factors affecting growth, sporulation, pathogenicity and dissemination of Leptosphaer- 
ulina briosiana. Phytopathology 53:938-945.

30. Northcote, K. H., Bettenay, E., Churchward, H. M., and McArthur, N. M. 1967. Explanatory data for sheet 5 , Perth-Albany-Esperance area. Atlas of Australian soils. CSIRO and Melbourne University Press, Melbourne, Australia.

31. O'Neill, N. R., Bauchan, G. R., and Samac, D. A. 2003. Reactions in the annual Medicago spp. core germ plasm collection to Phoma medicaginis. Plant Dis. 87:557-562.

32. Renfro, B. L., and Sprague, E. W. 1959. Reaction of Medicago species to eight alfalfa pathogens. Agron. J. 51:481-483.

33. Rhodes, L. H., and Myers, D. K. 1986. Severity of spring black stem on alfalfa cultivars in Ohio. Plant Dis. 70:746-748.

34. Sampson, K., and Western, J. H. 1941. Diseases of British Grasses and Herbage Legumes. Cambridge University Press, London.
35. Smith, J. F., Jagusch, K. T., Brunswick, L. F. C., and Kelley, R. W. 1979. Coumestans in lucerne and ovulation in ewes. N.Z. J. Agric. Res. 22:411-416.

36. Tivoli, B., Baranger, A., Sivasithamparam, K., and Barbetti, M. J. Invited Review: Annua Medicago - From a model crop challenged by a spectrum of necrotrophic pathogens to a model plant to explore the nature of disease resistance. Ann. Bot. 98:1117-1128. 